\title{
Distinct Subunits in Heteromeric Kainate Receptors Mediate Ionotropic and Metabotropic Function at Hippocampal Mossy Fiber Synapses
}

\author{
Arnaud Ruiz, ${ }^{1 *}$ Shankar Sachidhanandam, ${ }^{1 *}$ Jo Kristian Utvik, ${ }^{2}$ Françoise Coussen, ${ }^{1}$ and Christophe Mulle ${ }^{1}$ \\ ${ }^{1}$ Laboratoire de Physiologie Cellulaire de la Synapse, Centre National de la Recherche Scientifique, Unité Mixte de Recherche 5091, Université Bordeaux 2, \\ 33077 Bordeaux, France, and ${ }^{2}$ Centre for Molecular Biology and Neuroscience, Institute of Basic Medical Sciences, University of Oslo, N-0317 Oslo, Norway
}

\begin{abstract}
Heteromeric kainate receptors (KARs) containing both glutamate receptor 6 (GluR6) and KA2 subunits are involved in KAR-mediated EPSCs at mossy fiber synapses in CA3 pyramidal cells. We report that endogenous glutamate, by activating KARs, reversibly inhibits the slow $\mathrm{Ca}^{2+}$-activated $\mathrm{K}^{+}$current $I_{\text {sAHP }}$ and increases neuronal excitability through a G-protein-coupled mechanism. Using KAR knockout mice, we show that KA2 is essential for the inhibition of $I_{\text {sAHP }}$ in CA3 pyramidal cells by low nanomolar concentrations of kainate, in addition to GluR6. In GluR6 ${ }^{-1-}$ mice, both ionotropic synaptic transmission and inhibition of $I_{\text {sAHP }}$ by endogenous glutamate released from mossy fibers was lost. In contrast, inhibition of $I_{\text {sAHP }}$ was absent in KA2 ${ }^{-1-}$ mice despite the preservation of KAR-mediated EPSCs. These data indicate that the metabotropic action of KARs did not rely on the activation of a KAR-mediated inward current. Biochemical analysis of knock-out mice revealed that KA2 was required for the interaction of KARs with $\mathrm{G} \alpha_{\mathrm{q} / 11}$-proteins known to be involved in $I_{\text {sAHP }}$ modulation. Finally, the ionotropic and metabotropic actions of KARs at mossy fiber synapses were differentially sensitive to the competitive glutamate receptor ligands kainate $(5 \mathrm{~nm})$ and kynurenate $(1 \mathrm{~mm})$. We propose a model in which KARs could operate in two modes at mossy fiber synapses: through a direct ionotropic action of GluR6, and through an indirect G-protein-coupled mechanism requiring the binding of glutamate to $\mathrm{KA} 2$.
\end{abstract}

Key words: hippocampus; CA3; kainate receptors; slow AHP; mossy fiber synapse; excitability; glutamate

\section{Introduction}

Kainate receptors (KARs) play a critical role in the regulation of neuronal circuits and synaptic plasticity in the brain (Kullmann, 2001; Huettner, 2003; Lerma, 2003). In the hippocampus, postsynaptic KARs mediate an EPSC with slow kinetics in CA3 pyramidal neurons (Castillo et al., 1997; Vignes and Collingridge, 1997; Mulle et al., 1998), thus providing a temporal summation of synaptic signals transmitted by dentate granule cell axons, the mossy fibers. In addition to ionotropic signaling involving KARs, KAR agonists have been reported to reduce transmitter release by a G-protein-mediated activation of phospholipase C (PLC) and protein kinase C (PKC) (Rodriguez-Moreno et al., 1997; Cunha et al., 2000; Frerking et al., 2001). KARs functionally coupled to

\footnotetext{
Received June 3, 2005; revised 0ct. 28, 2005; accepted Nov. 3, 2005.

This work was supported by the Centre National de la Recherche Scientifique, European Commission Grant QLG3-CT-02089 (C.M., A.R., J.K.U.), the Conseil Régional d'Aquitaine, and the French Ministry for Foreign Affairs (S.S.). We thank Steve Heinemann and the Salk Institute for making the mutant mice available. We are grateful to 0 . Manzoni, D. Perrais, G. Casassus, B. Lancaster, and D. Kullmann for critical reading of this manuscript and to Magda Giordano for preparation of brain membranes.

*A.R. and S.S. contributed equally to this work.

Correspondence should be addressed to Christophe Mulle, Laboratoire de Physiologie Cellulaire de la Synapse, Centre National de la Recherche Scientifique, Unité Mixte de Recherche 5091, Université Bordeaux 2, 1 rue Camille Saint-Saëns, 33077 Bordeaux, France. E-mail: mulle@u-bordeaux2.fr.

A. Ruiz's present address: Department of Clinical and Experimental Epilepsy, Institute of Neurology, University College London, Queen Square, London WC1N 3BG, UK.

D0I:10.1523/JNEUROSCI.4041-05.2005

Copyright $\odot 2005$ Society for Neuroscience $\quad$ 0270-6474/05/2511710-09\$15.00/0
}

G-proteins inhibit N-type $\mathrm{Ca}^{2+}$ channels in dorsal root ganglia neurons (Rozas et al., 2003), under conditions that do not require ion permeation through the KAR channel. Recently, it has been shown that postsynaptic KARs enhance CA1 pyramidal cell excitability by inhibiting the slow afterhyperpolarization (sAHP) generated by a voltage-independent, $\mathrm{Ca}^{2+}$ dependent $\mathrm{K}^{+}$current $\left(I_{\text {sAHP }}\right)$ (Melyan et al., 2002, 2004). This inhibition of $I_{\text {sAHP }}$ was prevented by inhibitors of G-protein-dependent cascades and was mimicked by a high-frequency train of stimuli designed to activate Schaffer collaterals projecting onto CA1 pyramidal cells (Melyan et al., 2004). Furthermore, a similar $I_{\text {sAHP }}$-mediated increase in CA3 pyramidal cell excitability was observed during bath application of KA (Fisahn et al., 2004, 2005). Thus, evidence builds up that KARs can operate in two modes: (1) by a well characterized ionotropic action and (2) by an indirect regulation of ion channels through activation of G-proteins. The mechanisms underlying the metabotropic action of KARs remain to be elucidated, because KARs do not belong to the metabotropic glutamate receptor (mGluR) family, which comprise seventh transmembrane receptors directly coupled to specific G-proteins.

Functional studies in KAR subunit mutant mice have demonstrated that CA3 pyramidal neurons express KARs composed of GluR6 and KA2 subunits (Mulle et al., 1998; Contractor et al., 2003), consistent with anatomical studies (Petralia et al., 1994; Bureau et al., 1999; Darstein et al., 2003). At present, the role of 
the KA1 and KA2 subunits in the function of native KARs is unclear. Both KA1 and KA2 have a significant higher affinity for KA than do GluR5-GluR7 (Werner et al., 1991; Herb et al., 1992). When expressed in heterologous systems, KA1 and KA2 subunits do not form functional homomeric receptor channels but rather coassemble with GluR5-Glu7 to modulate pharmacological and biophysical properties of recombinant KARs (Huettner, 2003; Lerma, 2003). Ionotropic signaling mediated by postsynaptic KARs at hippocampal mossy fiber synapses requires the GluR6 subunit (Mulle et al., 1998). In KA2 $2^{-\prime-}$ mice, KAR-EPSCs display reduced decay kinetics in $\mathrm{KA} 2^{-/-}$mice (Contractor et al., 2003), although their amplitude is not significantly different from that measured in the wild type (Contractor et al., 2003). Thus, KA2 participates in postsynaptic KARs in CA3 pyramidal cells but is not required for their ionotropic function.

In this study, we show that low nanomolar concentrations of KA inhibit $I_{\text {sAHP }}$ in CA3 pyramidal cells and that KAR activation at mossy fiber synapses mimics this depression. By taking advantage of mice with specific deletions of either GluR6 or KA2, we describe a novel role for the high-affinity kainate receptor subunit KA2 in the brain. We show that KA2 is required for the metabotropic function of postsynaptic KARs. We propose that postsynaptic KARs operate in a bimodal manner through distinct binding sites for endogenous glutamate on GluR6 and KA2 subunits, and we show that these two sites can be dissociated by both genetic and pharmacological tools.

\section{Materials and Methods}

Electrophysiology. Transverse hippocampal slices (350 $\mu \mathrm{m}$ thick) were obtained from 2- to 4-week-old C56BL/6, GluR6 ${ }^{-1-}, \mathrm{KA} 2^{-1-}$, and GluR5/6 ${ }^{-1-}$ (on a hybrid $129 \mathrm{~Sv} \times \mathrm{C} 57 \mathrm{BL} / 6$ background) mice and were stored in an interface chamber for at least $1 \mathrm{~h}$ before transfer to a submersion recording chamber. The storage and perfusion solution contained the following (in $\mathrm{mM}$ ): $119 \mathrm{NaCl}, 2.5 \mathrm{KCl}, 1.3 \mathrm{MgSO}_{4}, 2.5 \mathrm{CaCl}_{2}$, $26.2 \mathrm{NaHCO}_{3}, 1 \mathrm{NaH}_{2} \mathrm{PO}_{4}$, and 11 glucose (gassed with $95 \% \mathrm{O}_{2} / 5 \%$ $\mathrm{CO}_{2}, 23-25^{\circ} \mathrm{C}$ ). Whole-cell and perforated-patch recordings were made from CA3 pyramidal cells under infrared differential interference contrast imaging. The following drugs were used to block AMPA, NMDA, GABA $A$, mGluRs, and GABA $_{B}$ receptors: GYKI 53655 [1-(4-aminophenyl)-3-methylcarbamyl-4-methyl-7,8-methylenedioxy3,4-dihydro-5H-2,3-benzodiazepine] $(50 \mu \mathrm{M})$, D-2-amino-5-phosphonovalerate (APV) $(50 \mu \mathrm{M})$, picrotoxin (PTX) $(100 \mu \mathrm{M})$, LY 341495 [(2S)-2-amino-2-[(1S,2S)-2-carboxycycloprop-1-yl]-3-(xanth-9-yl) propanoic acid] $(100 \mu \mathrm{M})$, and CGP 55845 [(2S)-3-\{[(15)-1-(3,4dichlorophenyl)ethyl] amino-2-hydroxypropyl)(phenylmeth-

yl)phosphinic acid] $(5 \mu \mathrm{M})$. TTX $(1 \mu \mathrm{M})$ was added to the perfusion solution to block action potential-dependent transmitter release, except for current-clamp experiments and for electrical stimulation of synaptic inputs. In the latter experiments, the $\mathrm{Na}^{2+}$ channel blocker QX314- $\mathrm{Br}$ [2(triethylamino)- $\mathrm{N}$-(2,6-dimethylphenyl) acetamine-bromo] (5 mM) was added to the internal pipette solution to prevent action potential generation. Tetraethylammonium (TEA) $(5 \mathrm{~mm})$ was routinely included in the mixture of antagonists to facilitate calcium spikes and reliably evoke $I_{\text {sAHP }}$. Whole-cell pipettes used to record $I_{\text {sAHP }}$ contained the following (in mM): $120 \mathrm{~K}$-methylsulfate, $8 \mathrm{NaCl}, 10 \mathrm{HEPES}, 0.2$ EGTA, 2 MgATP, and 0.3 $\mathrm{Na}_{3} \mathrm{GTP}$, pH 7.2 (osmolarity, $295 \mathrm{mOsm}$ ). The methylsulfate anion was used because it has been shown to preserve $I_{\mathrm{sAHP}}$ in a form similar to that observed with sharp electrode recordings (Lancaster and Adams, 1986). Current-clamp experiments were performed with a solution that contained the following (in $\mathrm{mm}$ ): $120 \mathrm{~K}$-gluconate, $8 \mathrm{NaCl}$, 10 HEPES, 0.2 EGTA, $2 \mathrm{MgATP}$, and $0.3 \mathrm{Na}_{3} \mathrm{GTP}$. The access and input resistances were monitored throughout the experiments using a voltage step. The access resistance was $<20 \mathrm{M} \Omega$ in whole-cell experiments, and results were discarded if it changed by $>20 \%$. For perforated-patch recordings, nystatin $(10 \mathrm{mg} / \mathrm{ml})$ was dissolved in acidified methanol. This stock solution was diluted with internal pipette solution just before use to a final concentration of $100-200 \mu \mathrm{g} / \mathrm{ml}$. Pipettes were backfilled with solution containing QX314-Br to monitor action potential blockade in case the perforated-patch configuration was lost. Steady-state access resistance of 40-60 M $\Omega$ was obtained 20-40 min after formation of a gigaseal. $I_{\mathrm{sAHP}}$ was elicited with intrasomatic depolarizing current pulses (duration, $80 \mathrm{~ms}$; amplitude, $50 \mathrm{mV}$ ) every $30-60 \mathrm{~s}$. Extracellular stimuli (stimulus duration, $50 \mu$ s; frequency, $20-100 \mathrm{~Hz} ; 1 \mathrm{~s}$ interval) used to evoke conditioning trains of EPSCs or EPSPs in CA3 pyramidal cells were delivered via a monopolar electrode positioned in the dentate granule cell layer such as to maximize mossy fiber responses. Mossy fiber responses were characterized by the marked facilitation of PSCs after switching stimulus frequency from 0.1 to $1 \mathrm{~Hz}$ and by their sensitivity to the group 2/3 mGluR agonist $\left(2 S, 1^{\prime} S, 2^{\prime} S\right)$-2-(carboxycyclopropyl)glycine (LCCG-1) $(10 \mu \mathrm{M})$ added to the perfusion medium at the beginning of experiments, before blocking mGluRs with LY 341495. In a separate set of experiments, the stimulating electrode was placed in the distal region of stratum radiatum to activate the perforant path, but no attempt was made to distinguish between medial and lateral inputs to CA3 pyramidal cells. The associative/commissural pathway was activated by placing the stimulating electrode in the $\mathrm{CA} 3$ stratum radiatum. Recordings were made using an EPC 8.0 amplifier (HEKA Elektronik, Lambrecht/Pfalz, Germany) and were filtered at $0.5-1 \mathrm{kHz}$, digitized at $1-5 \mathrm{kHz}$, and stored on a personal computer for additional analysis (IGOR PRO 5.0; WaveMetrics, Lake Oswego, OR). $I_{\text {sAHP }}$ amplitude was measured 350-500 ms after the depolarizing voltage step to minimize the contribution of the medium AHP (Martin et al., 2001). Statistical comparisons were made using Student's paired $t$ test or Wilcoxon's sum rank test for unpaired data when appropriate. K-methylsulfate was obtained from ICN Biomedicals (Irvine, CA), and other chemicals were from Tocris Cookson (Ballwin, MO) or Sigma (St. Louis, MO).

Immunocytochemistry and immunoblotting. We used the method of Yoneyama et al. (2004). In brief, 5-week-old mice were killed by decapitation, and the brains were taken out and quickly frozen. Sections were cut on a cryostat and fixed in Carnoy's solution containing 6:1 ethanol and acetic acid for $15 \mathrm{~min}$ at $4^{\circ} \mathrm{C}$. The sections were subsequently subjected to peroxidase quenching with $0.9 \% \mathrm{H}_{2} \mathrm{O}_{2}$ in $\mathrm{PBS}$ for $30 \mathrm{~min}$. The sections were incubated $1 \mathrm{~h}$ in blocking buffer containing $1.5 \%$ normal goat serum and $0.1 \%$ Triton X-100 in PBS, before they were incubated with anti-GluR6/7 and anti-KA2 antibody (Upstate Biotechnology, Lake Placid, NY) in blocking buffer at $4^{\circ} \mathrm{C}$ overnight. Sections were rinsed before they were incubated with donkey anti-rabbit antibody coupled to biotin (Amersham Biosciences, Arlington Heights, IL) in blocking solution for $30 \mathrm{~min}$ at room temperature. The sections were further rinsed and incubated in a solution of avidin and biotinylated peroxidase at room temperature for $30 \mathrm{~min}$ ( $\mathrm{ABC}$ kit; Vector Laboratories, Burlingame, CA). Sections were rinsed and subsequently reacted with 0.7 $\mathrm{mg} / \mathrm{ml} 3,3^{\prime}$-diaminobenzidine tetrahydrochloride in $60 \mathrm{~mm}$ Tris buffer containing $0.02 \% \mathrm{H}_{2} \mathrm{O}_{2}$ (FASTTM; Sigma).

For immunoblotting, brain membranes from different mouse genotypes were purified as by Coussen et al. (2002). Twenty micrograms of membranes were loaded on a $8 \%$ acrylamide SDS gel. Western blots were reprobed for tubulin (catalog \#T4026; Sigma) to verify the amount of proteins loaded on each lane. For immunoprecipitation, brain membranes were purified and solubilized with $1 \%$ Triton X-100 as by Coussen et al. (2002). Two milliliters (5 mg of proteins) of Triton X-100 extract were incubated with $3 \mu \mathrm{l}$ of anti-GluR6/7 antibody (catalog \#06-309; Upstate Biotechnology, Lake Placid, NY) and $30 \mu \mathrm{l}$ of protein-G Sepharose overnight at $4^{\circ} \mathrm{C}$. Resins were then washed with the loading buffer containing $500 \mathrm{~mm} \mathrm{NaCl}$ and resuspended in SDS sample buffer. Western blots were probed with an anti-GluR6/7, anti-KA2 (catalog \#06-315; Upstate Biotechnology, Lake Placid, NY) and anti-G $\alpha_{\mathrm{q} / 11}$ (catalog \#371754; Calbiochem, La Jolla, CA) antibodies. Pictures of the blots were taken with the ChemiGenius 2XE apparatus under the control of GeneSnap program. Quantities of proteins of interest were analyzed by densitometry with the corresponding Genetool analysis program (Syngene, Frederick, MD). 

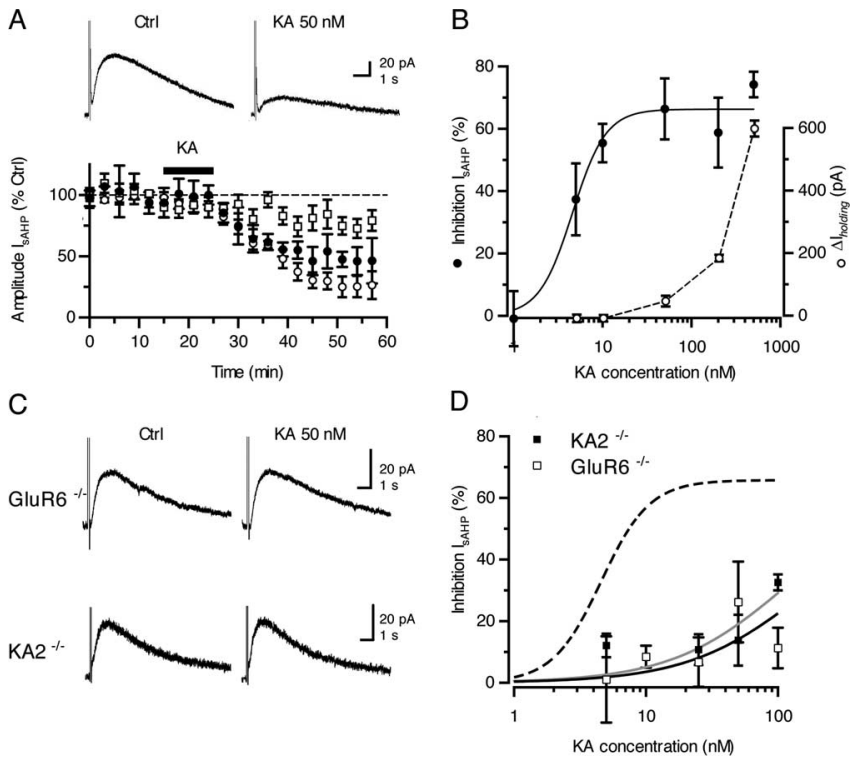

Figure 1. Activation of high-affinity binding KAR subunit KA2 by low nanomolar concentrations of KA modulates $I_{\text {sAHP }}$ in CA3 pyramidal neurons. $A, I_{\text {sAHP }}$ amplitude (mean \pm SEM) plotted against time $(n=4)$, showing a reduction evoked by bath perfusion of 5 and 50 nм KA (open squares and filled circles, respectively). A gentle rundown was observed when no KA was applied (open circles). Insets show sample traces of $I_{\text {sAHP }}$ before and after KA application (average of 5 consecutive traces). $\boldsymbol{B}$, Dose-response curve for KA-induced inhibition of $I_{\text {sAHP }}$ and relative changes in somatic holding current obtained in wild-type mice (a given KA concentration was tested in at least 3 cells; $n=21$ ). Data from KA-induced inhibition of $I_{\text {sAHP }}$ were fitted with the least-square method, which gave an $\mathrm{EC}_{50}$ of $6 \mathrm{~nm}$. Inhibition of $I_{\text {sAHP }} 0$ ccurred at low doses of KA $(5-50 \mathrm{~nm})$ without a significant shift in somatic holding current. C, Average of five consecutive traces taken before and after application of $50 \mathrm{~nm} \mathrm{KA}$ in $\mathrm{GluR6}^{-1-}$ and $\mathrm{KA2} 2^{-1-}$ mice. $\boldsymbol{D}$, Dose-response curves for $\mathrm{KA}$-induced inhibition of $I_{\text {sAHP }}$ obtained in $\mathrm{GluR6}^{-1-}$ and $\mathrm{KA2} 2^{-1-}$ knock-out mice ( $n=4$ cells for each concentration, from $5 \mathrm{GluR6}^{-1-}$ and $5 \mathrm{KA}^{-1-}$ mice). The dose-response relationship obtained with low concentrations of KA in wild-type was replotted for comparison. CA3 pyramidal cells were held in voltage clamp at $-60 \mathrm{mV}$ with a K-methylsulfate-based solution, in the presence of TTX (1 $\mu \mathrm{m})$, TEA (5 mm), PTX (100 $\mu \mathrm{m})$, CGP $55845(5 \mu \mathrm{M})$, APV $(50 \mu \mathrm{M})$, LY $341495(100 \mu \mathrm{M})$, and GYKI $53655(50 \mu \mathrm{M})$, to block voltagedependent $\mathrm{Na}^{2+}$ and $\mathrm{K}^{+}$channels, $\mathrm{GABA}_{\mathrm{A}}$ and $\mathrm{GABA}_{\mathrm{B}}$ receptors, NMDA receptors, metabotropic glutamate receptors, and AMPA receptors. The bar charts show mean \pm SEM values. ${ }^{*} p<0.05$. Ctrl, Control.

\section{Results \\ Regulation of $I_{\text {sAHP }}$ in CA3 pyramidal cells by low nanomolar KA concentration}

$I_{\text {sAHP }}$ was elicited in CA3 pyramidal cells with intrasomatic depolarizing current pulses (duration, $80 \mathrm{~ms}$; amplitude, $50 \mathrm{mV}$ ) every 30-60 s. Under these conditions, $I_{\text {sAHP }}$ amplitude was $77 \pm 11$ $\mathrm{pA}$ (mean \pm SEM) and decayed with a time constant of $3.8 \pm$ $0.6 \mathrm{~s}(n=21)$. After KA (50 nM) application, the amplitude of $I_{\text {sAHP }}$ irreversibly decreased by $75 \pm 8 \%$ and reached a plateau after $20 \min (n=4)$ (Fig. $1 A)$. In the absence KA, $I_{\text {sAHP }}$ amplitude was decreased by only $21 \pm 8 \%(n=6)$ (Fig. 1A) $60 \mathrm{~min}$ after breaking into whole cell. The effect of KA on $I_{\text {sAHP }}$ was dose dependent, with an $\mathrm{EC}_{50}$ of $6 \mathrm{nM}$ (Fig. $1 \mathrm{~B}$ ). At this concentration, KA inhibited $I_{\text {sAHP }}$ without significant variation in somatic holding current (Fig. $1 B$ ) and input resistance (supplemental Fig. $1 A$, available at www.jneurosci.org as supplemental material), consistent with ionotropic and non-ionotropic effects of KA. Higher concentrations of KA evoked inward currents (200 nM KA, $184 \pm$ 10 pA; $n=3$ ), as described previously (Castillo et al., 1997; Mulle et al., 1998). Preincubating slices with the AMPA/KA receptor antagonists CNQX $(20 \mu \mathrm{M})$ or NBQX $(50 \mu \mathrm{M})$ blocked the inhibition of $I_{\mathrm{sAHP}}$ observed with low doses of KA (supplemental Fig.
$1 B$, available at www.jneurosci.org as supplemental material). As in CA1 pyramidal cells (Melyan et al., 2002), the application of the PKC inhibitor calphostin $\mathrm{C}(1 \mu \mathrm{M})$ and the PTX-sensitive G-protein blocker N-ethylmaleimide $(50 \mu \mathrm{M})$ attenuated the KAevoked reduction of $I_{\text {sAHP }}$ (supplemental Fig. $1 C$, available at www.jneurosci.org as supplemental material). These data show that KAR activation by low nanomolar concentration of KA triggers a long-lasting inhibition of $I_{\mathrm{sAHP}}$ in CA3 pyramidal cells without activating a detectable inward current, by acting via a cascade of cellular events that mobilizes G-proteins and PKC (Melyan et al., 2002; Fisahn et al., 2005).

\section{The high-affinity KAR subunit KA2 regulates $I_{\text {sAHP }}$}

To identify the subunits mediating the modulation of $I_{\text {sAHP }}$, we measured the effect of $\mathrm{KA}$ in GluR6 ${ }^{-1-}$ or $\mathrm{KA} 2^{-1-}$ mutant mice (Mulle et al., 1998; Contractor et al., 2003). We observed no significant differences in $I_{\mathrm{SAHP}}$ characteristics obtained from GluR6 $^{-1-}(n=9)$ and KA2 ${ }^{-1-}(n=10)$ mice compared with wild-type mice, in terms of peak amplitude $(65 \pm 9$ and $90 \pm 15$ pA for GluR6 ${ }^{-1-}$ and $\mathrm{KA}^{-1-}$ mice, respectively) and decay time constant $\left(5.0 \pm 1.5\right.$ and $5.9 \pm 1.3 \mathrm{~s}$ for GluR6 ${ }^{-1-}$ and KA2 ${ }^{-1-}$ mice, respectively) (supplemental Fig. $1 C$, available at www. jneurosci.org as supplemental material). KA had no significant effect on $I_{\text {sAHP }}$ amplitude in either GluR6 ${ }^{-1-}$ or KA2 ${ }^{-/-}$mutant mice at concentrations up to $25 \mathrm{~nm}$ (Fig. 1C,D). These results imply that, in addition to GluR6 (Fisahn et al., 2005), KA2 subunits are required for the depression of $I_{\text {sAHP }}$ observed with low nanomolar KA concentration. We formulated the hypothesis that the lack of effect of KA on $I_{\text {sAHP }}$ in GluR6 ${ }^{-1-}$ mice was indirectly attributable to the loss of the KA2 protein. Indeed, GluR6 has a relatively low affinity for KA compared with the KA2 subunit (Bettler et al., 1992). We thus examined hippocampal sections from wild-type, GluR6 ${ }^{-1-}$, and $\mathrm{KA}^{-1-}$ mice with antiGluR6/7 and anti-KA2 antibodies. In wild-type mice, both antibodies prominently labeled stratum lucidum in which mossy fibers contact CA3 pyramidal cells, thus confirming previous results (Petralia et al., 1994). Hippocampal sections from GluR6 $^{-/-}$mice were not immunoreactive for GluR6/7 and were also devoid of immunoreactivity with antibodies against KA2. In contrast, GluR6/7 immunoreactivity was present normally in stratum lucidum of $\mathrm{KA}^{-l-}$ mice (Fig. $2 A$ ). In Western blots from hippocampal membrane preparation, the band labeled by the specific KA2 antibody was decreased by $87 \pm 8 \%$ in GluR6 $^{-1-}$ mice (different from wild-type with $p<0.01 ; n=5$ ), suggesting that the amount of KA2 protein critically depends on that of GluR6 (Christensen et al., 2004) (Fig. 2 B). In total brain, the level of KA2 protein returned to normal in transgenic mice, in which inactivation of GluR6 was rescued by a myc-GluR6 transgene under the control of the $\alpha$-calcium/calmodulin-dependent kinase II promoter (Coussen et al., 2002) (data not shown). Thus, the lack of regulation of $I_{\mathrm{sAHP}}$ by low nanomolar KA in GluR6 ${ }^{-I-}$ mice can be attributed to the indirect downregulation of KA2. Altogether, our results support the notion that the high-affinity KA binding subunit KA2 is necessary for $I_{\text {sAHP }}$ regulation by KARs.

In CA1 pyramidal cells, the G-protein $\mathrm{G} \alpha$ is responsible for the modulation of $I_{\mathrm{sAHP}}$ by muscarinic and glutamatergic agonists (Krause et al., 2002). We performed coimmunoprecipitation experiments to determine whether native KARs are associated with $\mathrm{G} \alpha_{\mathrm{q}}$, using an antibody that recognizes both $\mathrm{G} \alpha_{\mathrm{q}}$ and $\mathrm{G} \alpha_{11}$. The anti-GluR6 antibody immunoprecipitated both GluR6 and KA2, which form heteromers in native KARs (Fig. 2C) (Wenthold et al., 1994). In wild-type and GluR5 ${ }^{-/-}$mice, $\mathrm{G} \alpha \alpha_{\mathrm{q} / 11}$ 
A

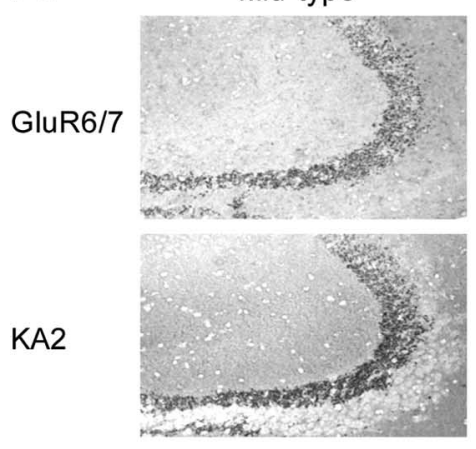

B

KA2

Tubulin
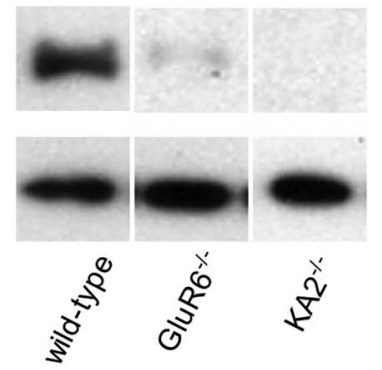

GluR6 ${ }^{-1-}$

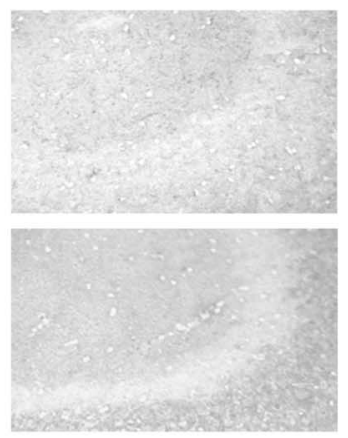

C

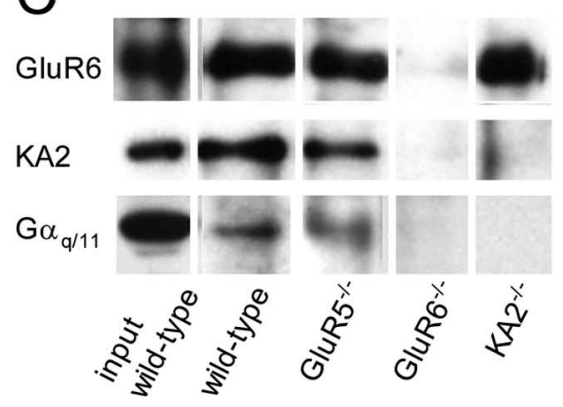

Figure 2. The KA2 subunit is responsible for the modulation of $I_{\text {sAHP }}$ in CA3 pyramidal cells. $A$, Immunostaining of hippocampal sections from wild-type, $\mathrm{GluR6}^{-1-}$, and $\mathrm{KA2}^{-1-}$ mice with anti-GluR6/7 and anti-KA2 antibodies. Both antibodies labeled stratum lucidum but not stratum radiatum and show a loss of $\mathrm{KA2}$ immunoreactivity in the CA3 region in GluR6 ${ }^{-1-}$ mice. $\boldsymbol{B}$, Western blot analysis of KA2 proteins in hippocampal membranes prepared from wild-type, $\mathrm{GluR6}^{-1-}$, and KA2 transgenic mice. To quantify the relative amount of proteins in each lane, Western blots were probed with a tubulin antibody. KA2 protein was not detected in $\mathrm{KA2}^{-1-}$ mice and greatly reduced in GluR6 ${ }^{-1-}$ mice (87\% of the wild-type amount). C, Using an anti-GluR6 antibody, a G-protein labeled by the anti-G $\alpha_{\mathrm{q} / 11}$ antibody was coimmunoprecipitated with the KA2 and GluR6 subunit in wildtype and $\mathrm{GluR5}^{-1-}$ mice and not in $\mathrm{KA2}^{-1-}$ mice.

was also immunoprecipitated under the same conditions with an anti-GluR6 antibody. In keeping with the hypothesis of a specific role for KA2, the biochemical interaction of $\mathrm{G} \alpha_{\mathrm{q} / 11}$ with KARs was lost in $\mathrm{KA}^{-1-}$ mice $(n=4)$, albeit in the presence of GluR6. In wild-type mice, when the KA2 subunit was immunoprecipitated with an anti-KA2 antibody, $\mathrm{G} \alpha_{\mathrm{q} / 11}$ was coimmunoprecipitated as well, albeit weakly, probably because the anti-KA2 antibody is directed against the C-terminal domain, which is likely necessary for interaction with $\mathrm{G} \alpha_{\mathrm{q} / 11}$ (data not shown). We also verified that there was no significant downregulation of $\mathrm{G} \alpha_{\mathrm{q} / 11}$ in $\mathrm{KA} 2^{-1-}$ mice ( $87 \pm 11 \% ; n=3$ compared with wild type; data not shown). These results suggest that $\mathrm{G} \alpha_{\mathrm{q}}$ (and/or $\mathrm{G} \alpha_{11}$ ) is the G-protein linking (directly or indirectly) KA2 to the modulation of $I_{\mathrm{sAHP}}$ in CA3 pyramidal cells.

\section{Synaptic regulation of $I_{\text {sAHP }}$ by KARs at mossy fiber synapses} KARs containing GluR6 and KA2 are present at mossy fiber synapses on CA3 pyramidal cells (Contractor et al., 2003). To test the possibility that synaptically released glutamate activates the metabolic cascade linking KARs to $I_{\mathrm{sAHP}}$, we delivered trains of stimuli to the dentate granule cell layer to recruit mossy fibers, and we observed the effect of these trains on $I_{\mathrm{sAHP}}$. With AMPA receptors were selectively blocked by GYKI $53655(50 \mu \mathrm{M})$, trains of stimuli evoked EPSCs with the characteristic features of mossy fiber synaptic currents (Fig. 3A) (see Materials and Methods). $I_{\mathrm{sAHP}}$ amplitude measured $350 \mathrm{~ms}$ after the last train was reduced by $24 \pm$ $5 \%(n=14 ; p<0.01)$ after three consecutive trains of five stimuli $\left(20 \mathrm{~Hz}, 1 \mathrm{~s}\right.$ interval) (Fig. 3B). A similar level of $I_{\mathrm{sAHP}}$ amplitude

depression was observed when the experiment was repeated at $32^{\circ} \mathrm{C}(27 \pm 6 \%$ depression; $n=6 ; p>0.1$ compared with results at room temperature; data not shown), albeit with an accelerated rundown of the $I_{\mathrm{sAHP}}$ amplitude. Synaptic modulation of $I_{\mathrm{sAHP}}$ was specific to the mossy fiber pathway, because no significant depression of $I_{\mathrm{sAHP}}$ amplitude was observed by activating perforant path synapses $(12 \pm 6 \%$ depression; $n=5 ; p>0.1)$ (Fig. $3 C$ ) or the associational/commissural pathway $(9 \pm 1 \%$ depression; $n=4 ; p>$ 0.1 ; data not shown). This finding is in agreement with the presence of postsynaptic KARs and high-affinity KA binding sites in stratum lucidum (Monaghan and Cotman, 1982), in which mossy fibers terminate (Amaral and Dent, 1981).

In contrast to KA bath application, the amplitude of $I_{\mathrm{sAHP}}$ rapidly recovered to baseline level after mossy fiber activation (Fig. 3B). Because the modulation of $I_{\mathrm{sAHP}}$ might be subject to dialysis of internal constituents of the cell, we repeated those experiments by using nystatin perforatedpatch recordings. With perforated-patch recordings, trains of stimuli eliciting mossy fiber responses decreased $I_{\mathrm{sAHP}}$ amplitude by $29 \pm 5 \%(n=5 ; p<0.05$ compared with just before the train), with a similar time course as that observed in whole-cell experiments (data not shown). Thus, the reversible depression of $I_{\mathrm{sAHP}}$ reported here does not depend on the loss of an important intermediate between KARs and $I_{\mathrm{sAHP}}$ channels. Increasing the interval between trains of stimuli and the test pulse for $I_{\mathrm{sAHP}}$ induction from $350 \mathrm{~ms}$ to $10 \mathrm{~s}$ showed that the modulation was abolished only if $I_{\mathrm{sAHP}}$ was induced $>5 \mathrm{~s}$ after trains $\left(I_{\mathrm{sAHP}}\right.$ inhibition for $10 \mathrm{~s}$ delay, $4 \pm 6 \% ; n=5$ ) (Fig. $3 D$ ). The presence of a depression of $I_{\mathrm{SAHP}}$, elicited long after synaptic activation, is consistent with the hypothesis that metabolic cascades are activated by KARs when glutamate is released.

The firing frequency of dentate granule cells is normally low $(<1 \mathrm{~Hz})$. However, the frequency can increase greatly $(10-40$ $\mathrm{Hz}$ ) when rats enter the place field of a granule cell (Jung and McNaughton, 1993). As predicted, a greater inhibition was evoked at $100 \mathrm{~Hz}$ (three trains of five stimuli; 1 s interval; $36 \pm 1 \%$ depression; $n=4$ ) compared with the inhibition of $I_{\mathrm{sAHP}} \mathrm{ob}-$ tained with $20 \mathrm{~Hz}$ stimulation (three trains of five stimuli; $1 \mathrm{~s}$ interval; $27 \pm 2 \%$ depression; $n=4$ ) (Fig. $3 E$ ). A lesser inhibition of $I_{\mathrm{sAHP}}$ was observed with a single train of five stimuli (19 $\pm 3 \%$ depression at $100 \mathrm{~Hz} ; n=4)$. Thus, inhibition of $I_{\mathrm{sAHP}}$ by synaptic activation of KARs was dependent on the frequency and number of stimulus trains. However, $I_{\mathrm{sAHP}}$ inhibition was in all cases reversible even when the number of stimuli within individual trains was increased (three trains of 100 stimuli at $20 \mathrm{~Hz} ; 1 \mathrm{~s}$ interval; $n=3$; data not shown). Moreover, high-frequency trains of stimuli used to induce long-term potentiation at mossy fiber synapses (three trains at $100 \mathrm{~Hz}$ for $1 \mathrm{~s} ; 10 \mathrm{~s}$ interval; $n=3$ ) resulted in an inhibition of $I_{\text {sAHP }}(39 \pm 9 \%$ depression; $n=3)$, which was fully reversible within $30 \mathrm{~s}$. Furthermore, no significant inhibition of $I_{\mathrm{SAHP}}$ was observed with high-frequency stim- 
A

Train d.g.

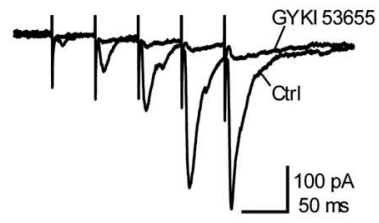

Train d.g. (with GYKI 53655)
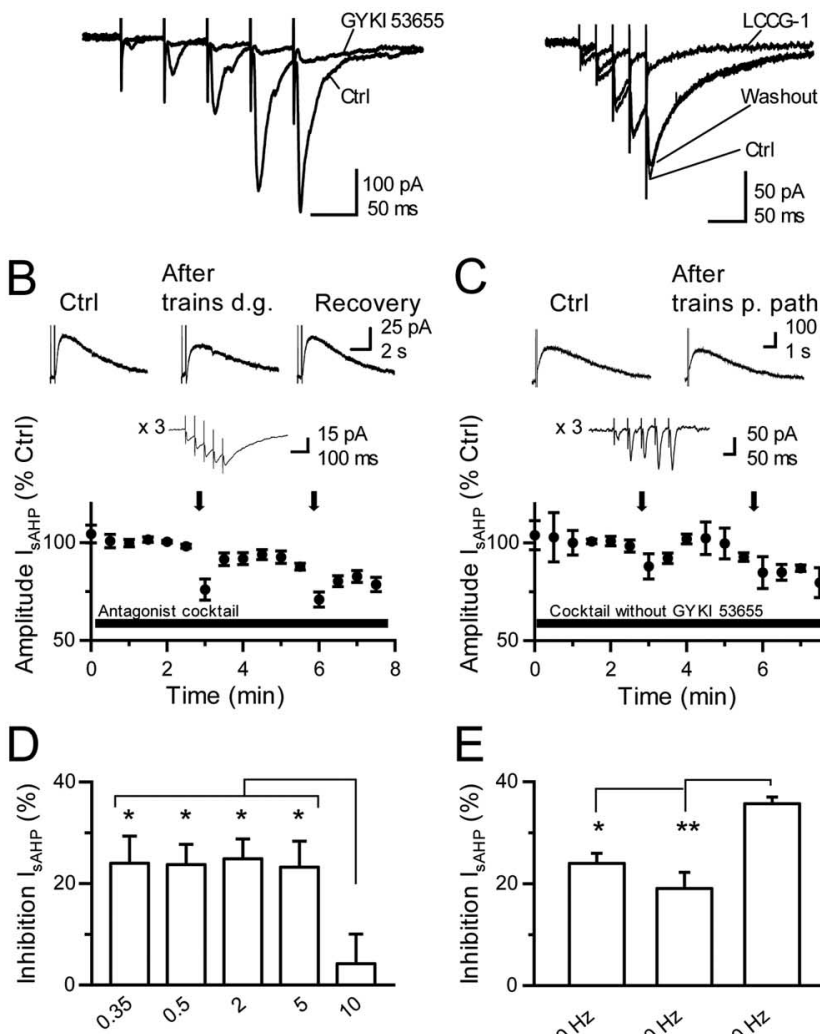

Interval test $\mathrm{I}_{\mathrm{SAHP}}(\mathrm{s})$
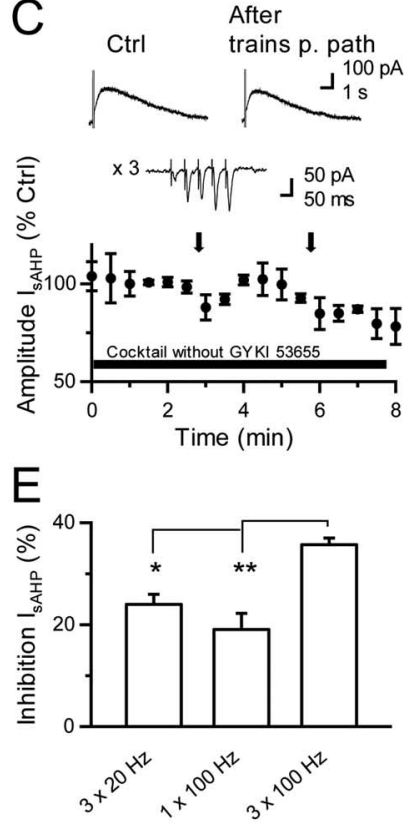

Figure 3. Endogenous glutamate inhibits $I_{S A H P}$ via KARs. $A$, Left, Sample recordings showing the prominent facilitation of EPSCs evoked by trains of stimuli $(20 \mathrm{~Hz})$ applied to the dentate gyrus (d.g.) in the absence (Ctrl) and presence of GYKI 53655. Blocking AMPA/KA receptors with GYKI $53655(50 \mu \mathrm{m})$ revealed the characteristic slow KAR-EPSCs, with frequency-dependent facilitation of postsynaptic currents in CA3 pyramidal neurons (average of 5 traces). Right, Superimposed traces showing consecutive sample recordings of KAR-EPSCs in the presence of GYKI $53655(50 \mu \mathrm{M})$, induced by trains of stimuli $(20 \mathrm{~Hz})$ at 1 s interval, in the absence (Ctrl), presence (LCCG-1), and after the washout of LCCG-1 (10 $\mu \mathrm{M})$. These characteristics point to KAR-EPSCs with a physiological and pharmacological profile typical of mossy fiber synapses. $\boldsymbol{B}$, Time course of $I_{\text {sAHP }}$ amplitude $(n=14)$ in whole-cell mode showing a reversible decrease after $20 \mathrm{~Hz}$ tetanic stimulation in the dentate gyrus as indicated by the arrows. After obtaining a stable $I_{\text {sAHP, }}$, three trains of five stimuli $(20 \mathrm{~Hz})$ were delivered at $1 \mathrm{~s}$ interval, and $I_{\text {sAHP }}$ was resumed $350 \mathrm{~ms}$ later. Insets show (top) sample recordings of $I_{\text {SAHP }}$ before (average of 3 traces), $350 \mathrm{~ms}$ after the first series of trains (single trace), and after recovery; (bottom) average of five KAR-EPSCs evoked by the trains of stimuli. C, Effect of perforant-pathway (p. path) activation on $I_{\text {sAHP. }}$. The same protocol as that applied for dentate stimulation was used to activate perforantpath synapses. AMPA receptors were not blocked, and $I_{\text {sAHP }}$ was resumed $350 \mathrm{~ms}$ after the last train. The amplitude of $I_{\text {SAHP }}$ plotted against time illustrates a nonsignificant decrease after trains of stimuli were delivered at the perforant path as indicated by the arrows. Sample traces (top) show $I_{\text {sAHP }}$ before (average of 3 traces) and $350 \mathrm{~ms}$ after the last train of stimuli (single trace); average of five EPSC traces (bottom) evoked by the trains of stimuli. D, Summary chart showing that increasing the interval between trains of stimuli and the test pulse for $I_{\text {sAHP }}$ induction from $350 \mathrm{~ms}$ to 5 s resulted in $I_{\text {sAHP }}$ inhibition ( 0.5 s delay, $24 \pm 4 \%, n=5$; 2 s delay, $25 \pm 4 \%, n=4 ; 5$ s delay, $23 \pm 5 \%, n=3$ ), which showed no significant difference from that obtained with a delay of $350 \mathrm{~ms}(p>0.1 ; n=6)$. $\boldsymbol{E}$, Increased stimulus frequency yields greater inhibition of $I_{\text {SAHP. }}$. The bar chart shows $I_{\text {SAHP }}$ inhibition in each condition (average of 3- 4 cells per condition). The antagonist mixture contained TEA (5 mM), PTX (100 $\mu \mathrm{M})$, APV (50 $\mu \mathrm{M})$, CGP $55845(5 \mu \mathrm{M})$, LY $341495(100 \mu \mathrm{M})$, and GYKI $53655(50 \mu \mathrm{M})$, except in C, in which GYKI 53655 was omitted. ${ }^{*} p<0.05 ;{ }^{* *} p<0.01$.

ulation applied to the associational/commissural pathway ( $9 \pm$ $4 \%$ depression, $n=3$ at one train of five stimuli at $100 \mathrm{~Hz} ; 11 \pm$ $4 \%$ depression, $n=3$ at three trains of five stimuli at $100 \mathrm{~Hz}$; data not shown). This contrasts with the irreversible depression of

$I_{\text {sAHP }}$ observed in CA1 pyramidal cells with $100 \mathrm{~Hz}$ stimulation of the Schaffer collateral pathway (Melyan et al., 2004) but is consistent with the regulation of $I_{\text {sAHP }}$ by mGluR agonists (Young et al., 2004). We repeated the experiments (three trains of five stimuli at $20 \mathrm{~Hz} ; 1 \mathrm{~s}$ interval) in the presence of DL-threo-hbenzyloxyaspartate (TBOA) $(50 \mu \mathrm{M})$, to see whether activation of putative extrasynaptic KARs might result in an irreversible inhibition of $I_{\text {sAHP. }}$. We saw no difference in the amplitude of KAREPSCs or in the depression of $I_{\mathrm{sAHP}}$ after the stimulus trains before and after TBOA application $(n=4 ; p>0.1)$ (data not shown). We confirmed that synaptic activation of KARs depresses $I_{\text {sAHP }}$ by adding the AMPA/KA receptor blocker NBQX to the mixture of antagonists. NBQX $(25 \mu \mathrm{M})$ not only suppressed KAR-EPSCs but also blocked the synaptic modulation of $I_{\text {sAHP }}$ in whole-cell ( $7 \pm 4 \%$ depression; $n=7 ; p<0.01$ compared with stimulus trains without NBQX) (Fig. $4 A, F$ ) and perforatedpatch $(n=5)$ (Fig. $4 F)$ experiments. It is known that $I_{\text {sAHP }}$ can be modulated by the activation of serotoninergic (5-HT), dopaminergic (DA), noradrenergic (NE), and cholinergic (ACh) receptors. Blockade of NE (propanolol, $1 \mu \mathrm{M}$; coryanthine, $5 \mu \mathrm{M}$; yohimbine, 5 $\mu \mathrm{M}), 5$-HT [SB-269970 [(2R)-1-(3-hydroxyphenyl)sulphonyl-22-(4-methyl-1-piperidinyl)ethylpyrrolidine], $0.1 \mu \mathrm{M}$; ketanserin, $10 \mu \mathrm{M}$; WAY 100635 (N-[2-[4-(2-methoxyphenyl)-1-piperazinyl] ethyl]-N-(2-pyridinyl)cyclo-hexane carboxamide trihydrochloride), $1 \mu \mathrm{M})$ ], DA [SCH-23390 $(R(+)$-7-chloro-8-hydroxy3-methyl-1-phenyl-2,3,4,5-tetrahydro-1H-3-benzazepine hydrochloride), $10 \mu \mathrm{M}$; sulpiride, $20 \mu \mathrm{M}$ ] and ACh (atropine sulfate, $1 \mu \mathrm{M}$ ) receptors did not enhance or diminish the level of $I_{\text {sAHP }}$ inhibition $(28 \pm 2 \% ; n=6 ; p>0.1$ compared with in the absence of monoamine or cholinergic antagonists; data not shown). Hence, these results eliminate the possibility that NBQX could have acted on putative presynaptic KARs on monoamine or cholinergic modulatory fibers. Preincubation of slices with 1 $\mu \mathrm{M}$ calphostin $\mathrm{C}$, an inhibitor of PKC, for 2-4 h blocked $I_{\text {sAHP }}$ inhibition after trains of stimuli $(n=5)$ (Fig. $4 B, F)$. We used the PLC $\beta$ inhibitor U73122 (1-[6[[(17 $\beta)$-3-methoxyestra1,3,5(10)-trien-17-yl] amino] hexyl]- $1 H$-pyrrole-2,5-dione) (10 $\mu \mathrm{M})$, and its inactive form U73343 (1-[6-((17 $\beta$-3-methoxyestra1,3,5(10)-trien-17-yl)amino)hexyl]-2,5-pyrrolidine-dione) (10 $\mu \mathrm{M})$, to verify the role of G-proteins and PLC $\beta$ activation in $I_{\text {sAHP }}$ modulation. After incubating the slices for $1 \mathrm{~h}$, U73122 blocked poststimulus $I_{\mathrm{sAHP}}$ inhibition ( $8 \pm 3 \%$ depression; $n=5$ ) (Fig. $4 C, F$ ), unlike U73343 (29 $\pm 5 \%$ depression; $n=5 ; p<0.01$ ) (Fig. $4 D, F)$. Furthermore, addition of GDP- $\beta$-s $(0.5 \mathrm{~mm})$ into the patch pipette resulted in a blockade of $I_{\mathrm{sAHP}}$ modulation and a stabilization of rundown (Fig. 4E). An accentuation of rundown was observed when GTP- $\gamma$-s (0.1 mM) was applied instead (Fig. $4 E$ ), suggesting that G-protein activation was responsible for the rundown. Altogether, these results argue that endogenous glutamate activates KARs at mossy fiber synapses and modulates $I_{\text {sAHP }}$ via G-protein, PLC $\beta$, and PKC activation.

To investigate the physiological relevance of the modulation of $I_{\text {sAHP }}$ by KARs, we examined the effect of stimulus trains on action potential discharge and spike frequency in CA3 pyramidal cells. We evoked spike discharge by applying a 200 pA depolarizing pulse for $1 \mathrm{~s}$ in the current-clamp mode. Under control conditions, a burst of spikes ( $3.2 \pm 0.3$ spikes; $n=4)$ was evoked at the beginning of the pulse. When the somatic depolarizing pulse was applied $350 \mathrm{~ms}$ after a train of stimuli that evoked KAREPSPs in CA3 pyramidal cells, the number of spikes elicited reversibly increased to $5.0 \pm 0.5$ ( $n=4$; different from control, $p<$ 0.01 ) (Fig. 5). Thus, activation of KARs by endogenous glutamate 
A

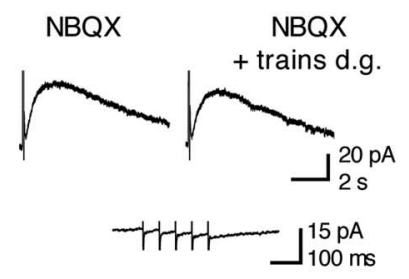

C
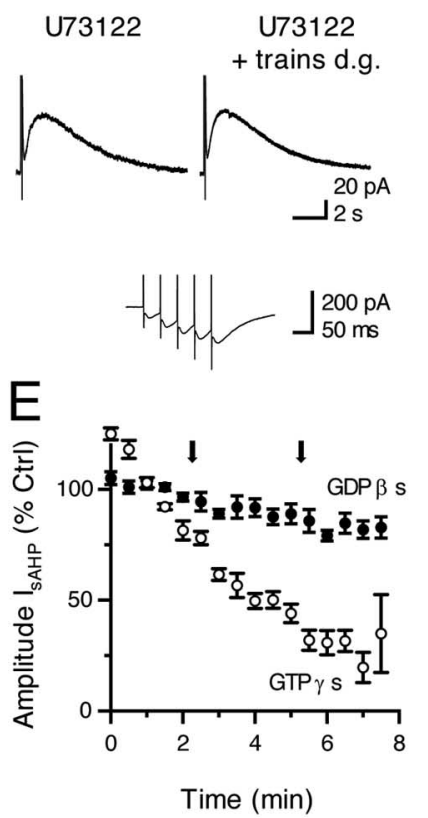

Time (min)
B

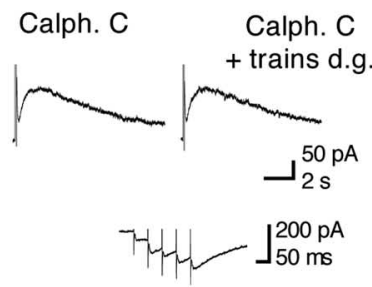

D
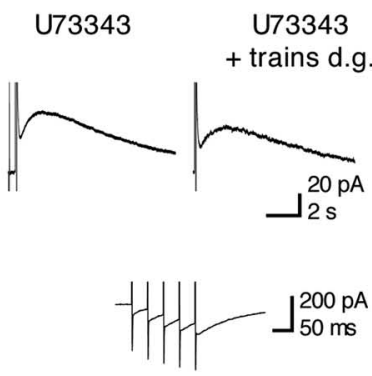

$\mathrm{F}$

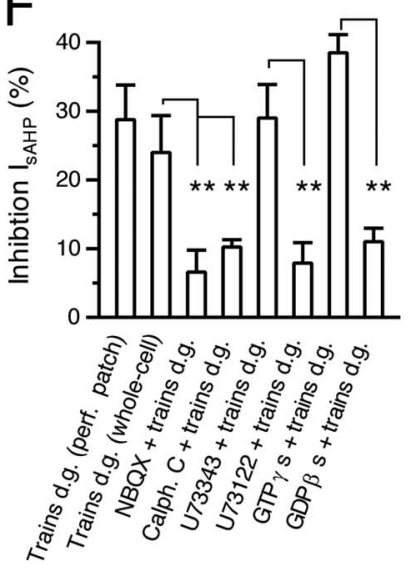

A

Before

After trains d. g.
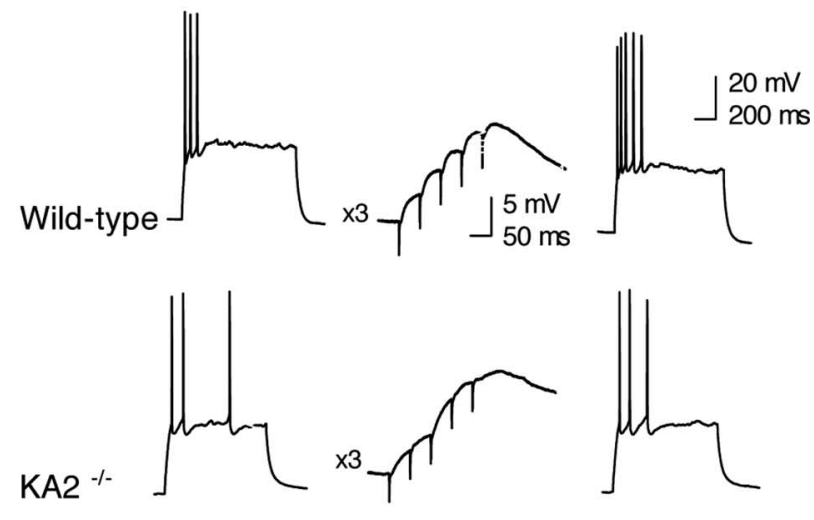

B

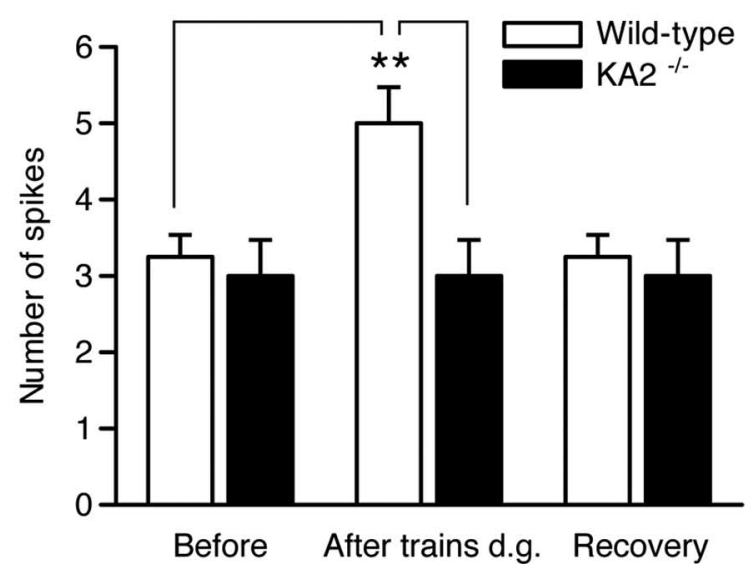

Figure 5. Regulation of spike frequency and excitability by synaptic KARs in CA3 pyramidal cells. $A$, Sample traces evoked by a $1 \mathrm{~s}$ depolarizing pulse taken from wild-type and $\mathrm{KA} 2^{-1-}$ mice, before (left) and after (right) trains of stimuli applied in the dentate gyrus (d.g.) (3 trains of 5 stimuli; $20 \mathrm{~Hz}$ ). Middle traces illustrate KAR-EPSPs evoked by a single train of stimuli. An increase in the number of spikes after trains of stimuli was observed in wild-type mice only. Membrane potential was $-60 \mathrm{mV}$. $\boldsymbol{B}$, Bar chart shows the average number of spikes (mean \pm SEM) before and after trains of stimuli, indicating a significant increase in excitability in wild-type $(n=4)$ but not KA2 ${ }^{-1-}(n=4$ cells, from 3 mice $)$ mice. The increase in spike number observed in wild-type mice returned to baseline value $30 \mathrm{~s}$ after stimulation (recovery). ${ }^{* *} p<0.01$.

by the AMPA receptor antagonist GYKI 53655 in GluR6 $^{-1-}$ mice but not in $\mathrm{KA} 2^{-l-}$ mice (Fig. $6 A, B$ ), in which the amplitude of KAR-EPSCs is comparable with that obtained from wild-type mice (Fig. 6B) (Mulle et al., 1998; Contractor et al., 2003). Trains of stimuli that elicited mossy fiber responses had little effect on $I_{\text {sAHP }}$ amplitude in neither GluR6 ${ }^{-1-}$ nor $\mathrm{KA}^{-1-}$ mice (Fig. $6 C-E)$, despite the presence of GluR6 subunits and KAR-EPSCs in the latter. Similarly, the effect of stimulus trains on pyramidal cell firing recorded in current-clamp mode was absent in $\mathrm{KA} 2^{-1-}$ mice $(3.0 \pm 0.5$ in control conditions; $3.0 \pm 0.5,350 \mathrm{~ms}$ after the train of stimuli; $p>0.1 ; n=4$ cells) (Fig. 5 ). These results indicate that KA2 plays a critical role in the synaptic regulation of $I_{\text {sAHP }}$, independently of ion fluxes responsible for KAR-EPSCs.

Hence, GluR6 and KA2 subunits that constitute postsynaptic KARs at mossy fiber synapses seem to subserve distinct functions. GluR6 is necessary for the ionotropic action of postsynaptic KARs, whereas KA2 appears to be indispensable for the metabotropic function. We reasoned that ionotropic and metabotropic actions mediated by KARs could be dissociated by the use of

\section{Role of GluR6 and KA2 in the bimodal function of synaptic KARs}

We further determined the role of KA2 in the modulation of $I_{\text {sAHP }}$ induced by activation of synaptic KARs at mossy fiber synapses in KAR subunit mutant mice. Mossy fiber EPSCs were fully blocked not only depolarizes CA3 pyramidal cells but also increases postsynaptic excitability by inhibiting the slow afterhyperpolarization. 

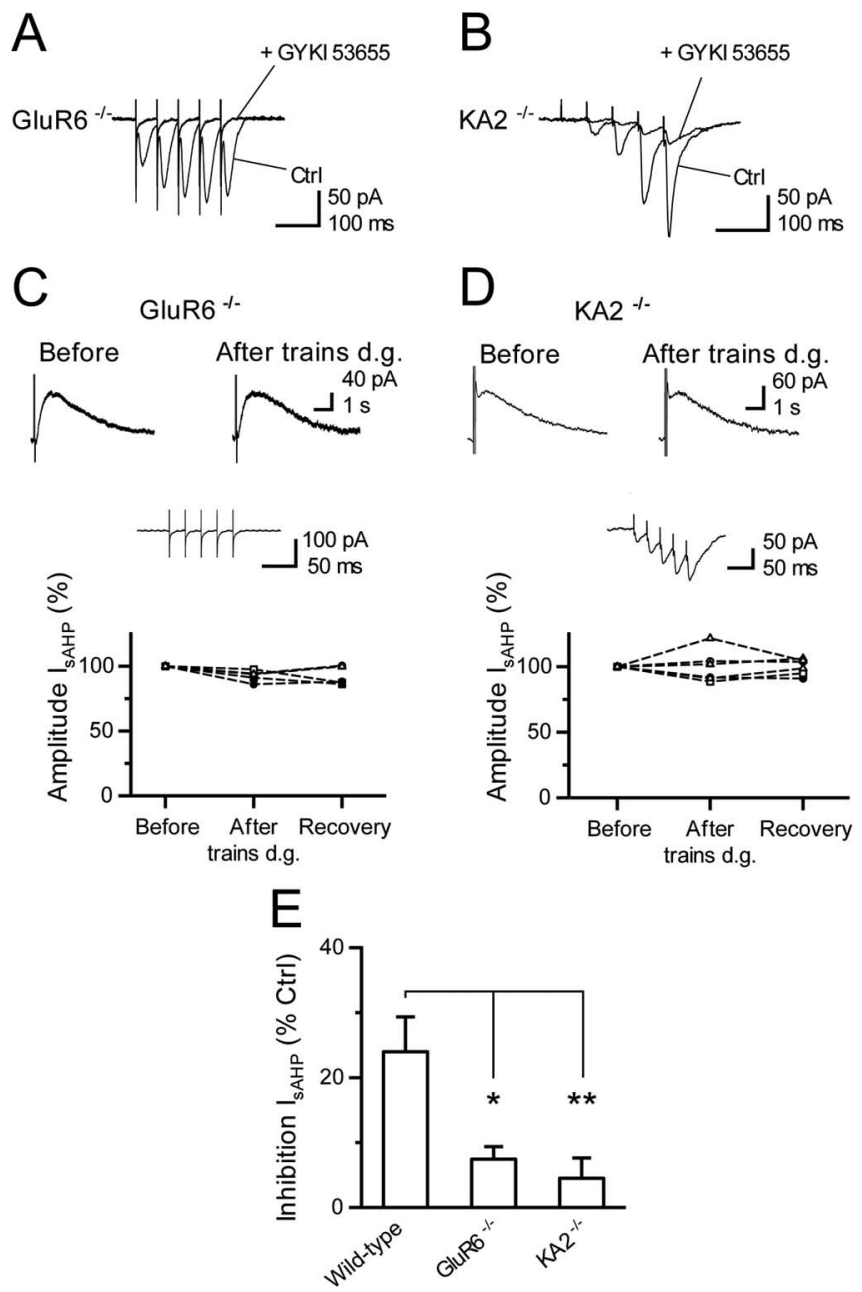

Figure 6. Absence of synaptic modulation of $I_{\text {sAHP }}$ in $\mathrm{GluR6}^{-1-}$ and $\mathrm{KA} 2^{-1-}$ mice. $\boldsymbol{A}, \boldsymbol{B}$, Sample traces showing the average of five consecutive EPSCs taken from GluR6 ${ }^{-1-}$ and $\mathrm{KA}^{-1-}$ mice, before (Ctrl) and after addition of GYKI 53655 (50 $\left.\mu \mathrm{M}\right)$. Trains of EPSCs displayed facilitation and disappeared during application of GYKI 53655 in GluR6 ${ }^{-1-}$ mice, confirming that they were mediated by AMPA receptors. In slices from $\mathrm{KA}^{-1-}$ mice, trains of stimuli elicited KAR-EPSCs with marked summation typical of mossy fiber responses. $C, D$, Plots of $I_{\text {sAHP }}$ amplitude showing the lack of synaptic modulation of $I_{\text {sAHP }}$ in $\mathrm{GluR6}^{-l-}(n=5)$ and KA2 $2^{-1-}$ $(n=6)$ mice. Insets show $I_{\text {sAHP }}$ before (averages of 3 traces) and after (single trace) the first series of trains. $\boldsymbol{E}$, The decrease in $I_{\text {sAHP }}$ amplitude after trains was $7 \pm 2 \%$ ( $n=5$ cells from 3 mice; $p<0.05$ compared with wild-type mice) and $5 \pm 3 \%$ ( $n=6$ cells from 3 mice; $p<$ $0.01)$, in GluR6 ${ }^{-1-}$ and $K A 2^{-1-}$, respectively, compared with that obtained in wild-type mice. ${ }^{*} p<0.05 ;{ }^{* *} p<0.01$. Ctrl, Control; d.g., dentate gyrus.

pharmacological agents that preferentially interact with glutamate binding sites on GluR6 and KA2, respectively. For instance, KA binds to KA2 with a higher affinity than to GluR6 (Herb et al., 1992). We applied a low concentration of KA ( $5 \mathrm{nM}$ ) and analyzed the effect on KAR-EPSCs and on the magnitude of stimulusinduced $I_{\text {sAHP }}$ modulation. Stimulus trains only induced a small inhibition of $I_{\text {sAHP }}$ in the presence of KA $5 \mathrm{nM}$ compared with untreated slices ( $9 \pm 4 \% I_{\text {sAHP }}$ amplitude reduction; $n=3$ ) (Fig. $7 A, C)$, suggesting that KA occluded $I_{\text {sAHP }}$ modulation by synaptically released glutamate. Concomitantly, KA reduced the amplitude of KAR-EPSCs by only $25 \pm 5 \%$ (both the first and fifth EPSCs; $n=3$ ). This reduction of KAR-EPSC amplitude was amplified at $50 \mathrm{nM}$ (reduction by $34 \pm 5 \%$; $n=3$; data not shown) and was reversible during KA washout, whereas inhibition of $I_{\text {sAHP }}$ remained (Fig. $1 A$ ). No change in facilitation of trains of AMPA EPSCs (without GYKI 53655) was observed before and
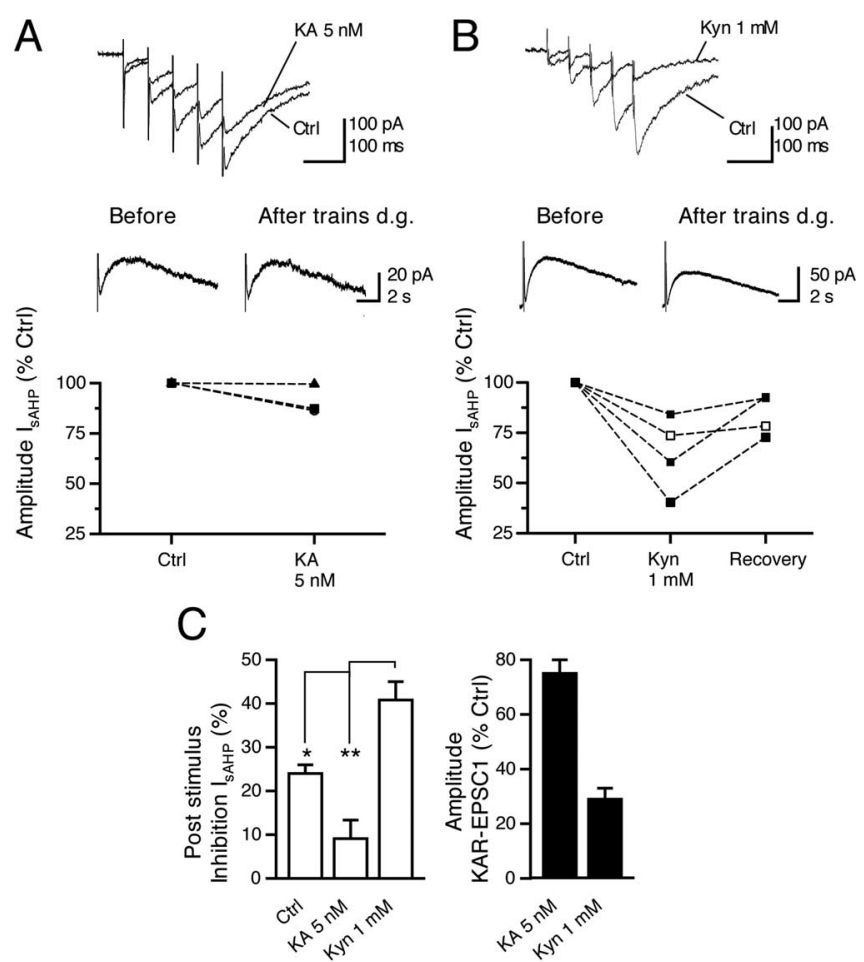

Figure 7. Pharmacological manipulation of ionotropic and metabotropic functions of synaptic KARs. $A$, Occlusion of the metabotropic action of KARs by low concentration of KA ( $5 \mathrm{~nm}$ ). Top, Sample traces (average of 5 traces) showing mossy fiber KAR-EPSCs without (Ctrl) and in the presence of KA. KA (5 nM) moderately reduced KAR-EPSC amplitude. Bottom, Plot showing little effect of mossy fiber synaptic modulation of $I_{\text {sAHP }}$ in the presence of KA $(5 \mathrm{~nm})(n=3)$. $\boldsymbol{B}$, Inhibition of KAR-EPSCs by Kyn (1 mm) and lack of effect on sAHP $_{\text {s. }}$ modulation. Top, Sample traces (average of 5 traces) show KAR-EPSCs in a CA3 pyramidal cell without (Ctrl) and with kynurenic acid ( $1 \mathrm{~mm}$ ). KAR-EPSCs were primarily inhibited by kynurenic acid $(n=4)$. Bottom, Plot of $I_{\text {sAHP }}$ amplitude in the presence of kynurenic acid ( $1 \mathrm{~mm}$ ), before (Ctrl) and after stimulus trains (Kyn, recovery) showing a reversible modulation. Insets in $\boldsymbol{A}$ and $\boldsymbol{B}$ show sample recordings of $\boldsymbol{I}_{\text {sAHP }}$ before (average of 3 traces) and after (single trace) stimulus trains. $C$, Bar charts summarizing the effect of KA ( $5 \mathrm{~nm}$ ) and kynurenic acid ( $1 \mathrm{~mm}$ ) on the magnitude of mossy fiber synaptic $I_{\text {sAHP }}$ inhibition and KAR-EPSCs. ${ }^{*} p<0.05 ;{ }^{* *} p<0.01$. d.g., Dentate gyrus.

after the application of $5 \mathrm{~nm} \mathrm{KA}(n=4 ; p>0.1$; data not shown), suggesting that the KAR-EPSC reduction was postsynaptic. These data suggest that low nanomolar KA preferentially occludes the metabotropic action of KARs possibly by binding with a higher affinity to the KA2 glutamate binding site. Conversely, the competitive glutamate receptor antagonist kynurenic acid (Kyn), which differentiates between GluR6 and GluR6/KA2 receptors by antagonizing glutamate currents at GluR6 (Alt et al., 2004), inhibited KAR-EPSCs in a dose-dependent manner with an $\mathrm{IC}_{50}$ of $0.49 \mathrm{~mm}$. At a concentration of $1 \mathrm{mM}$, Kyn decreased KAR-EPSC amplitude by $71 \pm 4 \%(n=4)$ but surprisingly increased $I_{\text {sAHP }}$ inhibition induced by activation of mossy fiber synapses $(35 \pm$ $4 \%$ amplitude reduction; $p<0.05$ compared with untreated slices) (Fig. $7 B, C$ ). These experiments suggest that the ionotropic and metabotropic actions mediated by postsynaptic KARs at mossy fiber synapses can be differentially antagonized by competitive ligands with different affinities for GluR6 and KA2.

\section{Discussion}

Several experiments have recently suggested that KARs not only function as ionotropic glutamate receptors but that they can also initiate a second-messenger cascade involving G-protein activation (Lerma, 2003). In particular, activation of KARs inhibits $I_{\text {sAHP }}$ elicited in pyramidal cells via G-protein and subsequent 
PKC activation (Melyan et al., 2002, 2004; Fisahn et al., 2005), thus signaling through a metabotropic route that enhances cortical excitability. Here we identify KA2 as the potential key subunit linking KARs to the regulation of cortical excitability, possibly through a specific interaction with $\mathrm{G} \alpha$, a G-protein involved in the regulation of $I_{\text {sAHP }}$ (Krause et al., 2002). We show for the first time that postsynaptic KARs can operate simultaneously through both ionotropic and metabotropic signaling. We propose that this bimodal activity of KARs is mediated by the binding of glutamate to two KAR subunits in a heteromeric complex, namely GluR6 and KA2.

\section{Modulation of $I_{\text {sAHP }}$ at mossy fiber synapses onto CA3 pyramidal cells}

We confirm that activation of KARs with KA inhibits $I_{\text {sAHP }}$ in CA3 pyramidal cells (Fisahn et al., 2005). We further demonstrate that synaptic activation of KARs at the mossy fiber synapse inhibits $I_{\text {sAHP }}$ in CA3 pyramidal cells, similar to what has been reported in the CA1 region (Melyan et al., 2002, 2004). The slow $\mathrm{Ca}^{2+}$-activated $\mathrm{K}^{+}$current $I_{\text {sAHP }}$, which follows a train of action potentials, is a privileged target for modulation of cell excitability by transmitter receptors. mGluRs (Heuss et al., 1999; Young et al., 2004), as well as cholinergic, monoaminergic, corticosteroid, and vasoactive intestinal peptide receptors, inhibit $I_{\mathrm{sAHP}}$ in the cortex and subcortical areas of the brain (Sah and Faber, 2002; Vogalis et al., 2003). We tested different stimulation protocols to induce glutamate release and KAR activation and found that the extent of $I_{\text {sAHP }}$ inhibition was amplified with repeated trains of stimuli that activated mossy fiber synapses. However, in all instances, the amplitude of $I_{\text {sAHP }}$ returned to baseline level within $30 \mathrm{~s}$. This temporal window of $I_{\mathrm{sAHP}}$ regulation by endogenous glutamate acting at KARs is compatible with an effect mediated by G-protein and protein kinase activation (Cox et al., 1994; Heuss et al., 1999; Cunha et al., 2000; Haug and Storm, 2000; Rodriguez-Moreno et al., 2000). This reversibility in CA3 pyramidal cells contrasts with the long-lasting inhibition of $I_{\text {sAHP }}$ observed in CA1 pyramidal cells when the Schaffer collateral pathway is activated (Melyan et al., 2004). The reason for this difference is unclear and might involve distinct KARs or distinct $I_{\text {sAHP }}$ channels. KARs involved in $I_{\text {sAHP }}$ modulation in CA1 pyramidal cells are likely to be extrasynaptic receptors and hence possibly linked to a different transduction mechanism. The latter might be a reason as well for the delayed and irreversible inhibition of $I_{\text {sAHP }}$ by KA compared with synaptic activation of KARs at the mossy fiber synapse in CA3 pyramidal cells. The conjunction between activity-dependent summation of KAR-EPSCs (Castillo et al., 1997; Vignes and Collingridge, 1997) and increased neuronal excitability through $I_{\text {sAHP }}$ modulation at mossy fiber synapses could provide a powerful mechanism to recruit CA3 pyramidal cells to firing threshold.

\section{Bimodal function of KARs through GluR6 and KA2}

The molecular basis of the metabotropic action of KARs is presently unknown. Our results provide a first insight into these mechanisms. GluR6 has been proposed to account for KAinduced inhibition of $I_{\text {sAHP }}$ (Melyan et al., 2002), because regulation of $I_{\text {sAHP }}$ was absent in GluR6 $6^{-/-}$mice (Fisahn et al., 2005) (this study). In fact, we propose that the lack of $I_{\text {sAHP }}$ inhibition in GluR6 $^{-1-}$ mice is a consequence of the loss of the KA2 protein in CA3 pyramidal cells. Indeed, immunohistochemical labeling in the CA3 region clearly demonstrated the lack of KA2 immunoreactivity in GluR6 ${ }^{-1-}$ mice. This is consistent with results showing that intracellular trafficking of KA2 is regulated by endoplasmic reticulum retention signals, which prevent the subunit expression at the plasma membrane in absence of one of the GluR5-GluR7 subunits (Ren et al., 2003). In addition, mutation of the RXR retention signal allows surface expression of homomeric KA2, but these receptors remain refractory to ionotropic activation (Ren et al., 2003), adding support to the notion that KA2 does not act as an ionotropic subunit on its own. Nevertheless, KA2 does contribute to GluR5/KA2 and GluR6/KA2 receptors (Swanson et al., 2002) and to KAR-EPSC kinetics (Contractor et al., 2003). Inhibition of $I_{\text {sAHP }}$ by KARs with low nanomolar affinity for KA depends on KA2, consistent with an action on the high-affinity KA binding site. Altogether, our results demonstrate a novel specific role for KA2 as a critical link between KAR activation and $I_{\text {sAHP }}$ regulation.

KARs at the mossy fiber synapse are likely to be heteromeric GluR6/KA2 receptors (Contractor et al., 2003). It is thus important to understand the role played by the coassembly of GluR6 with KA2 in synaptic transmission and cellular excitability. The difference in the sensitivity to KA in GluR6 versus GluR6/KA2 is small, with a slight increase in single-channel conductance reported with this combination (Howe, 1996). Whereas glutamate activates GluR6 and GluR6/KA2 steady-state currents with a similar efficacy (Alt et al., 2004), it is not known whether the efficacy of glutamate to activate the peak (nondesensitized) current is changed by coassembly of the two subunits. In $\mathrm{KA} 2^{-1-}$ mice, mossy fiber KAR-EPSCs are preserved and are likely mediated by GluR6 containing KARs. In these mice, inhibition of $I_{\text {sAHP }}$ is not observed strongly, suggesting that heteromeric receptors containing both GluR6 and the KA2 subunit are necessary for inhibition of $I_{\text {sAHP. }}$. One can suggest that GluR6 is the necessary subunit that drives KA2 to the plasma membrane and to synaptic sites, in which this subunit can then play its role in the metabotropic action of KARs. The ionotropic and metabotropic functions of synaptic KARs at mossy fiber synapses have been separated by pharmacological agents that preferentially bind to either GluR6 or KA2 (Herb et al., 1992; Alt et al., 2004). We showed that occupation of high-affinity KA binding sites with KA (5 nM) occluded poststimulus modulation of $I_{\text {sAHP }}$, with little effect on KAR-EPSCs. Conversely, the competitive glutamate receptor antagonist kynurenic acid (1 mM) blocked KAR-EPSCs but had little effect on $I_{\text {sAHP }}$ modulation. These results suggest that competitive ligands, which bind differentially to heteromeric synaptic KARs via either GluR6 or KA2 subunits, have differential effects on the ionotropic and metabotropic actions of synaptic KARs. Accordingly, we propose a hypothetical model of a single receptor complex with a bimodal function for native KARs through the binding of glutamate to two categories of sites at mossy fiber synapses: (1) an ionotropic function mediated by glutamate binding onto the GluR6 subunit and (2) a metabotropic function requiring glutamate binding onto the KA2 subunit. It is, however, possible that two separate groups of receptor complexes, and not one, are behind this dual function of KARs. In addition, we do not exclude a strong functional interaction between the binding sites of glutamate on the two subunits, when assembled within the same receptor complex. The lack of information on the biophysical properties of native KARs makes it difficult to resolve this issue at the moment. Finally, it should be noted that KA1 is another high-affinity kainate binding subunit also expressed by CA3 pyramidal cells that might contribute to postsynaptic KARs at the mossy fiber synapse (Darstein et al., 2003), although there are no indication as to its potential role. However, our results strongly suggest the presence of a simultaneous bimodal function of KARs at the mossy fiber-CA3 synapse.

The precise molecular mechanisms that link KARs to the ac- 
tivation of G-protein-mediated cascades have yet to be elucidated. Here we show that KARs interact with a G-protein (labeled by an anti-G $\alpha_{\mathrm{q} / 11}$ antibody) through KA2. Because $\mathrm{G} \alpha_{\mathrm{q}}$, and not $\mathrm{G} \alpha_{11}$, is specifically involved in the cholinergic and mGluR modulation of $I_{\mathrm{sAHP}}$ in CA1 neurons (Krause et al., 2002), it is possible that $\mathrm{G} \alpha_{\mathrm{q}}$ plays a similar role for KAR-induced $I_{\text {sAHP }}$ modulation. Because KA2 is necessary for the metabotropic action of KARs, we can speculate that interaction of $\mathrm{KA} 2$ with $\mathrm{G} \alpha_{\mathrm{q}}$ is a key element in the regulation of $I_{\text {sAHP. }}$ The cytoplasmic C-terminal domains of KAR subunits and splice variants show a high degree of divergence and are the privileged targets for binding to cytoplasmic partner proteins (Jaskolski et al., 2005). It will be important to determine, using biochemical approaches, whether $\mathrm{G} \alpha$ q directly or indirectly binds to KA2 and how this interaction is linked to G-protein activation.

\section{References}

Alt A, Weiss B, Ogden AM, Knauss JL, Oler J, Ho K, Large TH, Bleakman D (2004) Pharmacological characterization of glutamatergic agonists and antagonists at recombinant human homomeric and heteromeric kainate receptors in vitro. Neuropharmacology 46:793-806.

Amaral DG, Dent JA (1981) Development of the mossy fibers of the dentate gyrus. I. A light and electron microscopic study of the mossy fibers and their expansions. J Comp Neurol 195:51-86.

Bettler B, Egebjerg J, Sharma G, Pecht G, Hermans-Borgmeyer I, Moll C, Stevens CF, Heinemann S (1992) Cloning of a putative glutamate receptor: a low affinity kainate-binding subunit. Neuron 8:257-265.

Bureau I, Bischoff S, Heinemann SF, Mulle C (1999) Kainate receptormediated responses in the CAl field of wild-type and GluR6-deficient mice. J Neurosci 19:653-663.

Castillo PE, Malenka RC, Nicoll RA (1997) Kainate receptors mediate a slow postsynaptic current in hippocampal CA3 neurons. Nature 388:182-186.

Christensen JK, Paternain AV, Selak S, Ahring PK, Lerma J (2004) A mosaic of functional kainate receptors in hippocampal interneurons. J Neurosci 24:8986-8993.

Contractor A, Sailer AW, Darstein M, Maron C, Xu J, Swanson GT, Heinemann SF (2003) Loss of kainate receptor-mediated heterosynaptic facilitation of mossy-fiber synapses in KA2-/ - mice. J Neurosci 23:422-429.

Coussen F, Normand E, Marchal C, Costet P, Choquet D, Lambert M, Mege RM, Mulle C (2002) Recruitment of the kainate receptor subunit glutamate receptor 6 by cadherin/catenin complexes. J Neurosci 22:6426-6436.

Cox CL, Metherate R, Ashe JH (1994) Modulation of cellular excitability in neocortex: muscarinic receptor and second messenger-mediated actions of acetylcholine. Synapse 16:123-136.

Cunha RA, Malva JO, Ribeiro JA (2000) Pertussis toxin prevents presynaptic inhibition by kainate receptors of rat hippocampal $\left[{ }^{3} \mathrm{H}\right] \mathrm{GABA}$ release. FEBS Lett 469:159-162.

Darstein M, Petralia RS, Swanson GT, Wenthold RJ, Heinemann SF (2003) Distribution of kainate receptor subunits at hippocampal mossy fiber synapses. J Neurosci 23:8013-8019.

Fisahn A, Contractor A, Traub RD, Buhl EH, Heinemann SF, McBain CJ (2004) Distinct roles for the kainate receptor subunits GluR5 and GluR6 in kainateinduced hippocampal gamma oscillations. J Neurosci 24:9658-9668.

Fisahn A, Heinemann SF, McBain CJ (2005) The kainate receptor subunit GluR6 mediates metabotropic regulation of the slow and medium AHP currents in mouse hippocampal neurones. J Physiol (Lond) 562:199-203.

Frerking M, Schmitz D, Zhou Q, Johansen J, Nicoll RA (2001) Kainate receptors depress excitatory synaptic transmission at CA3 $\rightarrow$ CA1 synapses in the hippocampus via a direct presynaptic action. J Neurosci 21:2958-2966.

Haug T, Storm JF (2000) Protein kinase A mediates the modulation of the slow $\mathrm{Ca}^{2+}$-dependent $\mathrm{K}^{+}$current, I(sAHP), by the neuropeptides CRF, VIP, and CGRP in hippocampal pyramidal neurons. J Neurophysiol 83:2071-2079.

Herb A, Burnashev N, Werner P, Sakmann B, Wisden W, Seeburg PH (1992) The KA-2 subunit of excitatory aminoacid receptor shows widespread expression in brain and forms ion channels with distantly related subunits. Neuron 8:775-785.

Heuss C, Scanziani M, Gahwiler BH, Gerber U (1999) G-proteinindependent signaling mediated by metabotropic glutamate receptors. Nat Neurosci 2:1070-1077.

Howe J (1996) Homomeric and heteromeric ion channels formed from the kainate-type subunits GluR6 and KA2 have very small but different unitary conductances. J Neurophysiol 76:510-519.

Huettner JE (2003) Kainate receptors and synaptic transmission. Prog Neurobiol 70:387-407.

Jaskolski F, Coussen F, Mulle C (2005) Subcellular localization and trafficking of kainate receptors. Trends Pharmacol Sci 26:20-26.

Jung MW, McNaughton BL (1993) Spatial selectivity of unit activity in the hippocampal granular layer. Hippocampus 3:165-182.

Krause M, Offermanns S, Stocker M, Pedarzani P (2002) Functional specificity of $\mathrm{G} \alpha \mathrm{q}$ and $\mathrm{G} \alpha 11$ in the cholinergic and glutamatergic modulation of potassium currents and excitability in hippocampal neurons. J Neurosci 22:666-673.

Kullmann DM (2001) Presynaptic kainate receptors in the hippocampus: slowly emerging from obscurity. Neuron 32:561-564.

Lancaster B, Adams PR (1986) Calcium-dependent current generating the afterhyperpolarization of hippocampal neurons. J Neurophysiol $55: 1268-1282$.

Lerma J (2003) Roles and rules of kainate receptors in synaptic transmission. Nat Rev Neurosci 4:481-495.

Martin ED, Araque A, Buno W (2001) Synaptic regulation of the slow $\mathrm{Ca}^{2+}$-activated $\mathrm{K}^{+}$current in hippocampal CAl pyramidal neurons: implication in epileptogenesis. J Neurophysiol 86:2878-2886.

Melyan Z, Wheal HV, Lancaster B (2002) Metabotropic-mediated kainate receptor regulation of IsAHP and excitability in pyramidal cells. Neuron 34:107-114.

Melyan Z, Lancaster B, Wheal HV (2004) Metabotropic regulation of intrinsic excitability by synaptic activation of kainate receptors. J Neurosci 24:4530-4534.

Monaghan D, Cotman C (1982) The distribution of $\left[{ }^{3} \mathrm{H}\right]$-kainic acid binding sites in rat CNS as determined by autoradiography. Brain Res 252:91-100.

Mulle C, Andreas S, Pérez-Otaño I, Dickinson-Anson H, Castillo PE, Bureau I, Maron C, Gage FH, Mann JR, Bettler B, Heinemann SF (1998) Altered synaptic physiology and reduced susceptibility to kainate induced seizures in GluR6-deficient mice. Nature 392:601-604.

Petralia R, Wang Y, Wenthold R (1994) Histological and ultrastructural localization of the kainate receptor subunits KA2, and GluR6/7, in the rat central nervous system using selective antipeptide antibodies. J Comp Neurol 349:85-110.

Ren Z, Riley NJ, Garcia EP, Sanders JM, Swanson GT, Marshall J (2003) Multiple trafficking signals regulate kainate receptor KA2 subunit surface expression. J Neurosci 23:6608-6616.

Rodriguez-Moreno A, Herreras O, Lerma J (1997) Kainate receptors presynaptically downregulate GABAergic inhibition in the rat hippocampus. Neuron 19:893-901.

Rodriguez-Moreno A, Lopez-Garcia JC, Lerma J (2000) Two populations of kainate receptors with separate signaling mechanisms in hippocampal interneurons. Proc Natl Acad Sci USA 97:1293-1298.

Rozas JL, Paternain AV, Lerma J (2003) Noncanonical signaling by ionotropic kainate receptors. Neuron 39:543-553.

Sah P, Faber ES (2002) Channels underlying neuronal calcium-activated potassium currents. Prog Neurobiol 66:345-353.

Swanson GT, Green T, Sakai R, Contractor A, Che W, Kamiya H, Heinemann SF (2002) Differential activation of individual subunits in heteromeric kainate receptors. Neuron 34:589-598.

Vignes M, Collingridge GL (1997) The synaptic activation of kainate receptors. Nature 388:179-182.

Vogalis F, Storm JF, Lancaster B (2003) SK channels and the varieties of slow after-hyperpolarizations in neurons. Eur J Neurosci 18:3155-3166.

Wenthold RJ, Trumpy VA, Zhu WS, Petralia RS (1994) Biochemical and assembly properties of GluR6 and KA2, two members of the kainate receptor family, determined with subunit-specific antibodies. J Biol Chem 269:1332-1339.

Werner P, Voigt M, Keinänen K, Wisden W, Seeburg PH (1991) Cloning of a putative high-affinity kainate receptor expressed predominantly in hippocampal CA3 cells. Nature 351:742-744.

Yoneyama M, Kitayama T, Taniura H, Yoneda Y (2004) Immunohistochemical detection by immersion fixation with Carnoy solution of particular non- $N$-methyl-D-aspartate receptor subunits in murine hippocampus. Neurochem Int 44:413-422.

Young SR, Chuang SC, Wong RK (2004) Modulation of afterpotentials and firing pattern in guinea pig CA3 neurones by group I metabotropic glutamate receptors. J Physiol (Lond) 554:371-385. 